\title{
REVIEW OF MECHANICAL VAPOUR COMPRESSION REFRIGERATION SYSTEM PART 2: PERFORMANCE CHALLENGE
}

\author{
R.A. MAHMOOD ${ }^{* 1}$ and O.M. ALI \\ Collage of Mechanical Engineering, University of Zakho, Kurdistan Region, IRAQ \\ ${ }^{1}$ School of Mechanical and Electrical Engineering, University of Southern Queensland \\ QLD 4350, AUSTRALIA \\ E-mail: raid.ahmed@uoz.edu.krd
}

\begin{abstract}
A. AL-JANABI
Department of Mechanical and Industrial Engineering, College of Engineering Sultan Qaboos University, OMAN
\end{abstract}

G. AL-DOORI

International College of Engineering and Management, OMAN

\author{
M.M. NOOR \\ Faculty of Mechanical \& Automotive Engineering Technology, Universiti Malaysia Pahang \\ 26600 Pekan, Pahang, MALAYSIA
}

\begin{abstract}
Reducing energy consumption and providing high performance for a vapour compression refrigeration system are big challenges that need more attention and investigation. This paper provides an extensive review of experimental and theoretical studies to present the vapour compression refrigeration system and its modifications that can be used to improve system's performance and reduce its energy consumption. This paper also presents the challenges that can be considered as a gab of research for the future works and investigations. Cooling capacity, refrigerant effect, energy consumption can be improved by using vapour injection technique, natural working fluid, and heat exchanger. Based on the outcome of this paper, vapour injection technique using natural refrigerant such as water can provide ultimate friendly refrigeration system. Future vision for the vapour compression refrigeration system and its new design technique using Computational Fluid Dynamic (CFD) is also considered and presented.
\end{abstract}

Key words: vapour compression, refrigeration systems, cycle, coefficient of performance (COP).

\section{Introduction}

Vapour compression refrigeration systems have been widely used in various industrial applications such as food storage, building, manufacturing and medicine [1]. The vapour compression refrigeration system consists of four main components named: compressor, condenser, expansion device, and evaporator [2-8]. These components are connected in order to produce the refrigeration effect through thermodynamic processes: compression, condensation, expansion, and evaporation [9-14]. There are man thermodynamic losses associated with isentropic vapour compression and constant enthalpy expansion due to high discharge temperature of the refrigerant, large power consumptions, rise in the condenser heat rejection, large throttling losses and drop in refrigeration capacity. These losses are big challenges that need to be considered to provide high system performance. Some technical improvement methods such as an injection technique, and

\footnotetext{
${ }^{*}$ To whom correspondence should be addressed
} 
intercooling technique can be used to improve the system performance [15-19]. In addition, refrigerant selection is another challenge that also needs to be considered to provide high performance and environmentally friendly vapour compression refrigeration systems.

There are many studies such as Mahmood, Buttsworth [20], Tuo and Hrnjak [21], Dhumane, Qiao [22] and Pathak, Binder [23], in which it was reported that the injection technique has a significant effect on the system performance and it can be used to improve the system capacity.

A gravitational vertical flash tank separator is one of the components that can be used to produce in the vapour compression refrigeration system. The vertical flash tank vapour injection (FTVI) is used to separate out the liquid of refrigerant from the gas-liquid two-phase flow and feed only liquid to the evaporator [23], while the vapour of the refrigerant is injected to the compressor. The FTVL technique reduces the thermal stress that would be generated in the compressor as a result of the electrical current flowing in the electrical coil of the compressor and compression process [24]. In the second stage cycle, the injected liquid of refrigerant will be sent to the second expansion device to feed the second stage evaporator. Consequently, the discharge temperature is decreased at the compressor outlet, that leads to an increase in the capacity with low ambient temperature conditions [25].

The gravitational vertical flash tank separator needs more attention to provide an optimum design. The optimum design of the separator demands some of the critical design parameters such as: the size of the pipe and its layout, cooling capacity, the volume of all evaporators and pipes that affect the separator, system dynamics [26].

Refrigerant's selection based on the thermodynamic performance and physical properties that influence system performance also need to be considered to ensure design of an effective vapour compression refrigeration system with high performance. In the open literature, there are many studies about the vapour compression refrigeration system. These studies focused on the improvement of the vapour compression refrigeration system performance based on system modification and refrigerant type. However, the vapour compression refrigeration system still needs to be improved to meet the user needs and obtain minimum energy consumption.

This paper will present a comprehensive review of the experimental and theoretical studies which were carried out to investigate the modification of the vapour compression refrigeration systems. This paper will assess and analyse the state of art of the theoretical and experimental studies to present a summary of the modification techniques that can be used to improve the performance of vapour compression refrigeration systems and reduce energy consumption. Future vision for the vapour compression refrigeration system and how to decrease the energy consumption will be presented in this paper.

\section{Vapour compression cycle}

A vapor compression refrigeration cycle has four elements: evaporator, compressor, condenser and expansion valve, respectively, as shown in Fi.1. [24, 27-32]. It uses the refrigerant as a working fluid which absorbs heat from the surrounding space to be cooled and subsequently rejects that heat elsewhere [28, 33, 34].

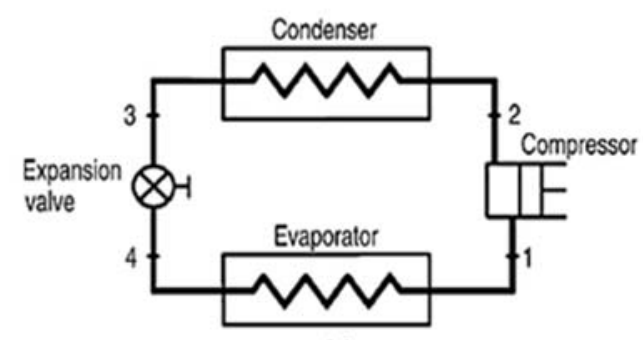

(a)

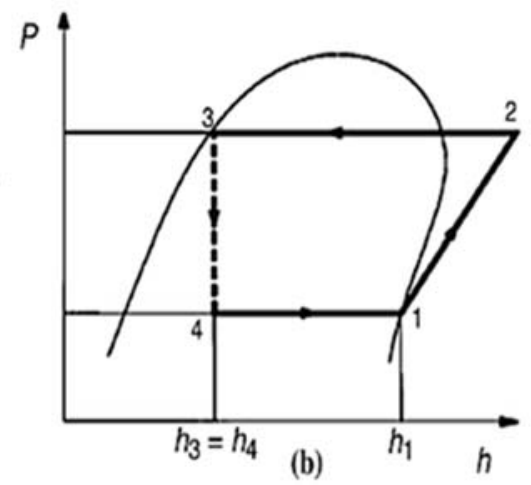

Fig.1. (a) Schematics and (b) P-h diagram of a vapor compression system [24]. 
The coefficient of performance (COP) and energy consumption need more attention to provide high performance with low energy consumption of a vapour compression refrigeration system. The vapour injection technique using vertical gravitational flash tank separator was used to improve the COP [11, 15, 35-37]. Winandy and Lebrun [38] reported that the vapour injection contributes to raise the compressor capacity with constant COP. The compressor discharge temperature is affected by using liquid injection. Wang, Hwang [8] reported that the COP is increased to $23 \%$ when the flash tank separator is used.

Many experimental and theoretical investigation studies have been made on the vapour compression refrigeration system and its modifications. Table 1 summarizes the result of research on vapour compression refrigeration systems.

Table 1a. Summary of research on vapour compression systems.

\begin{tabular}{|c|c|c|}
\hline References & Modification & Remarks \\
\hline Bolaji [39] & $\begin{array}{l}\text { Using R22 and ozone } \\
\text { friendly } \\
\text { refrigerants } \\
\text { and R507). }\end{array}$ & $\begin{array}{l}\text { - Experimental results showed that R22 had the lowest pressure } \\
\text { ratio and discharge temperature closely followed by R507. } \\
\text { - The average discharge temperature obtained using R507 and } \\
\text { R404A was } 4.2 \% \text { and } 15.3 \% \text { higher than that of R22, } \\
\text { respectively. } \\
\text { - The average refrigeration capacities of R507 and R404A were } \\
4.7 \% \text { higher and } 8.4 \% \text { lower than that of R22, respectively. } \\
\text { - The investigation has revealed that R507 can be used successfully } \\
\text { as a retrofitting refrigerant in existing window air-conditioners } \\
\text { originally designed to use R22 in the event of HCFC phased out. }\end{array}$ \\
\hline $\begin{array}{c}\text { Sun, Wang } \\
{[40]}\end{array}$ & Using heat pipe & $\begin{array}{l}\text { - The cooling capacity of the system has a nearly constant value of } \\
200 \mathrm{~kW} \text {, and EER changes from } 21.2 \text { to } 3.1 \text { when the outdoor } \\
\text { temperature increases from }-5^{\circ} \mathrm{C} \text { to } 45^{\circ} \mathrm{C} \text {. }\end{array}$ \\
\hline $\begin{array}{c}\text { Tao, } \\
\text { Hwang [41] }\end{array}$ & $\begin{array}{l}\text { Electrochemical } \\
\text { compressor for the } \\
\text { vapor compression } \\
\text { refrigeration cycle } \\
\text { running with ammonia } \\
\text { or carbon dioxide as its } \\
\text { working fluids. }\end{array}$ & $\begin{array}{l}\text { - The electrochemical compressor does not use any moving parts, } \\
\text { it does not need to use lubrication oil neither does it produce any } \\
\text { noise or vibration. } \\
\text { - It can potentially approach an isothermal compression for even } \\
\text { higher energy efficiency and thus improve the system } \\
\text { performance. }\end{array}$ \\
\hline $\begin{array}{l}\text { Agrawal, } \\
\text { Patil [42] }\end{array}$ & $\begin{array}{l}\text { Using the mixture of } \\
\text { R134a and LPG with } \\
\text { mass fractions of } 28: 72 \\
\text { as an alternative to } \\
\text { R134a }\end{array}$ & $\begin{array}{l}\text { - results show that the compressor power consumption, compressor } \\
\text { discharge temperature and pull down time obtained with } \\
\mathrm{R} 134 \mathrm{a} / \mathrm{LPG}(28: 72) \text { of } 118 \mathrm{~g} \text { and capillary tube length of } 5.1 \mathrm{~m} \text { in } \\
\text { vapor compression refrigeration system are about } 4.4 \% 2.4 \% \text { and } \\
5.3 \% \text {, respectively, lower than that obtained with } \mathrm{R} 134 \mathrm{a} \text { in the } \\
\text { studied range. }\end{array}$ \\
\hline $\begin{array}{l}\text { Shaik and } \\
\text { Babu [43] }\end{array}$ & $\begin{array}{l}\text { Thermodynamic } \\
\text { analysis of window air } \\
\text { conditioner with R431A, } \\
\text { R410A, R419A, R134a, } \\
\text { R1270, R290 and fifteen } \\
\text { refrigerant mixtures } \\
\text { consisting of R134a, } \\
\text { R1270 and R290 was } \\
\text { carried out based on } \\
\text { actual vapour compre- } \\
\text { ssion cycle. }\end{array}$ & $\begin{array}{l}\text { - COP for the refrigerant mixture } \mathrm{R} 134 \mathrm{a} / \mathrm{R} 1270 / \mathrm{R} 290(50 / 5 / 45 \text { by } \\
\text { mass percentage) is } 2.10 \% \text { higher among the } \mathrm{R} 22, \mathrm{R} 431 \mathrm{~A}, \mathrm{R} 410 \mathrm{~A} \text {, } \\
\mathrm{R} 419 \mathrm{~A}, \mathrm{R} 134 \mathrm{a}, \mathrm{R} 1270, \mathrm{R} 290 \text {, and fifteen studied refrigerant } \\
\text { mixtures. The compressor discharge temperature of all the studied } \\
\text { refrigerants were lower than that of } \mathrm{R} 22 \text { by } 4.8^{\circ} \mathrm{C}-22.2^{\circ} \mathrm{C} \text {. } \\
\text { - The power consumption per ton of refrigeration for the refrigerant } \\
\text { mixture R134a/R1270/R290 (50/5/45 by mass percentage) is } \\
2.01 \% \text { lower among R22, R431A, R410A, R419A, R134a, } \\
\mathrm{R} 1270, \mathrm{R} 290 \text {, and fifteen studied refrigerant mixtures. }\end{array}$ \\
\hline
\end{tabular}


Table 1b. Summary of research on vapour compression systems.

\begin{tabular}{|c|c|c|}
\hline $\begin{array}{l}\text { Choudhari } \\
\text { and Sapali } \\
\text { [44] }\end{array}$ & $\begin{array}{l}\text { Analyses the possibi- } \\
\text { lities of R290 as a } \\
\text { potential substitute } \\
\text { for R22. }\end{array}$ & $\begin{array}{l}\text { - Coefficient of performance with R290 is slightly lower than that } \\
\text { of R } 22 \text {. } \\
\text { - Higher COP can be expected in specially designed systems due } \\
\text { to the properties of R } 290 \text {. } \\
\text { - R290 can be a better substitute for R22 in real applications } \\
\text { because of its excellent environmental and thermophysical } \\
\text { properties. }\end{array}$ \\
\hline $\begin{array}{l}\text { Samuel, } \\
\text { Govindarajul } \\
\mathrm{u}[45]\end{array}$ & $\begin{array}{l}\text { Use R-22, R } 407 \mathrm{C} \text { and } \\
\text { R410A with different } \\
\text { capillary pitches. }\end{array}$ & $\begin{array}{l}\text { - R } 410 \text { A with a capillary pitch of } 18 \mathrm{~mm} \text { gave the best coefficient } \\
\text { of performance to retrofit window air conditioner working on } \\
\text { R22. }\end{array}$ \\
\hline $\begin{array}{c}\text { Devotta, } \\
\text { Padalkar [46] }\end{array}$ & $\begin{array}{l}\text { Experimental } \\
\text { performance study of } \\
\text { a window air } \\
\text { conditioner with } \\
\text { propane (HC-290), a } \\
\text { natural refrigerant, as } \\
\text { a drop-in substitute } \\
\text { for HCFC-22. }\end{array}$ & $\begin{array}{l}\text { - HC-290 had } 6.6 \% \text { lower cooling capacity for the lower operating } \\
\text { conditions and } 9.7 \% \text { lower for the higher operating conditions } \\
\text { compared to HCFC-22. }\end{array}$ \\
\hline $\begin{array}{l}\text { Santini, } \\
\text { Bianchi [47] }\end{array}$ & $\begin{array}{l}\text { Using } \mathrm{Co}_{2} \text { as a } \\
\text { working fluid. }\end{array}$ & $\begin{array}{l}\text { - Coefficient of Performance (COP) is strongly dependent on the } \\
\text { entrainment ratio; a value greater than } 0.6 \text { seems to lead to higher } \\
\text { COP values, even at low external temperatures. }\end{array}$ \\
\hline $\begin{array}{l}\text { Poachaiyapo } \\
\text { om, } \\
\text { Leardkun } \\
{[48]}\end{array}$ & $\begin{array}{l}\text { Using R134a with } \\
\text { electronics cooling } \\
\text { technique. }\end{array}$ & $\begin{array}{l}\text { - The highest COP gained is } 9.069 \text { at a compressor speed of } \\
3000 R P M \text { and a heating power of } 200 \mathrm{~W} \text {, which yields the heater } \\
\text { surface temperature of } 73.3^{\circ} \mathrm{C} \text {. } \\
\text { - The proposed system is not suitable for electronics cooling at a } \\
\text { heating power of } 100 \mathrm{~W} \text { and } 150 \mathrm{~W} \text {, because the heater surface } \\
\text { temperature is less than } 40^{\circ} \mathrm{C} \text {. }\end{array}$ \\
\hline $\begin{array}{l}\text { Branch and } \\
\text { Khalkhal } \\
\text { [49] }\end{array}$ & $\begin{array}{l}\text { Modelled the thermo- } \\
\text { dynamic properties of } \\
\text { refrigerants, condenser } \\
\text { and evaporator second- } \\
\text { dary fluid using an } \\
\text { artificial neural } \\
\text { network }\end{array}$ & $\begin{array}{l}\text { - Benefits and disadvantages of } \mathrm{R} 407 \mathrm{C} \text { as an alternative for } \\
\text { replacing R22 in refrigeration cycle were reported. }\end{array}$ \\
\hline $\begin{array}{c}\text { Devotta, } \\
\text { Padalkar [50] }\end{array}$ & $\begin{array}{l}\mathrm{R}-407 \mathrm{C} \quad \text { as } \\
\text { substitute for } \mathrm{R}-22\end{array}$ & $\begin{array}{l}\text { - R-407C has } 2.1 \% \text { lower cooling capacity for the lower outdoor } \\
\text { conditions and } 7.93 \% \text { lower for the higher outdoor conditions } \\
\text { compared to R-22. } \\
\text { - The cooling efficiency for R-407C is } 7.9 \% \text { lower for the lower } \\
\text { outdoor conditions and } 13.47 \% \text { lower for the higher outdoor } \\
\text { conditions. } \\
\text { - The discharge pressures measured for R-407C were higher in the } \\
\text { range } 11-13 \% \text { than for R-22. }\end{array}$ \\
\hline $\begin{array}{l}\text { Choi and } \\
\text { Kim [51] }\end{array}$ & $\begin{array}{l}\text { Effect of expansion } \\
\text { device on the } \\
\text { performance of a } \\
\text { water-to-water heat } \\
\text { pump using R407C. }\end{array}$ & $\begin{array}{l}\text { - R407C with electronic expansion device shows a more stable } \\
\text { compressor discharge temperature at off-design charge than the } \\
\text { R407C capillary tube system. }\end{array}$ \\
\hline
\end{tabular}


Table 1c. Summary of research on vapour compression systems.

\begin{tabular}{|c|c|c|}
\hline $\begin{array}{l}\text { Deymi- } \\
\text { Dashtebayaz } \\
\text { and } \\
\text { Valipour- } \\
\text { Namanlo } \\
\text { [52] }\end{array}$ & $\begin{array}{l}\text { Optimise mass flow } \\
\text { rate of the injected } \\
\text { refrigerant. }\end{array}$ & $\begin{array}{l}\text { - The optimization method indicated that a better performance is } \\
\text { obtained at injection mass flow rate of } 5.9 \mathrm{~kg} / \mathrm{s} \text { depending on the } \\
\text { exergy analysis. } \\
\text { - The ambient temperature and temperature of chilled water } \\
\text { entering the evaporator variation has no influence on the optimum } \\
\text { mass flow rate of the injected refrigerant. }\end{array}$ \\
\hline $\begin{array}{l}\text { Agarwal, } \\
\text { Arora [53] }\end{array}$ & $\begin{array}{lr}\text { Using } & \text { HFO- } \\
\text { R1234ze, } & \text { R1234yf } \\
\text { and HFC-R134a }\end{array}$ & $\begin{array}{l}\text { - The R1234ze may be an alternative to HFC-R134a and } \\
\text { supersedes R1234yf. }\end{array}$ \\
\hline $\begin{array}{l}\text { Jain, Jain } \\
\quad[54]\end{array}$ & $\begin{array}{l}\text { Using vapor injection } \\
\text { in scroll compressors } \\
\text { for air-conditioning } \\
\text { and refrigeration } \\
\text { applications. }\end{array}$ & $\begin{array}{l}\text { - COP increase of around } 6-8 \% \text { and a } \\
\text { displacement of } 16 \% \text { for air-condition }\end{array}$ \\
\hline $\begin{array}{l}\text { Hwang, } \mathrm{Xu} \\
\text { [55] }\end{array}$ & $\begin{array}{l}\text { Vapor refrigerant } \\
\text { injection cycle with a } \\
\text { flash tank. }\end{array}$ & $\begin{array}{l}\text { - The system was found to be opera } \\
\text { refrigerant in the flash tank maintain } \\
\text { the tank height to ensure the reliable }\end{array}$ \\
\hline
\end{tabular}

\section{Components design and sub-cooler}

Many studies have been done to provide new successful design for the vapour compression refrigeration system; the main aim of all previous studies was to improve the performance of the system. Some of these studies provided new modification and design for the vertical flash tank separator, new design for the compressor and using the intercooling technique (Mahmood, Buttsworth [36], [56, 57], Llopis, Nebot-Andrés [58]). Some of other studies used Computational Fluid Dynamic (CFD) to predict the effect of refrigerant flow development and its effect on separation and flow characteristic (Jangir and Jana [59], Kumar and Chandrasekar [60], and Sharifi, Sabeti [61]).
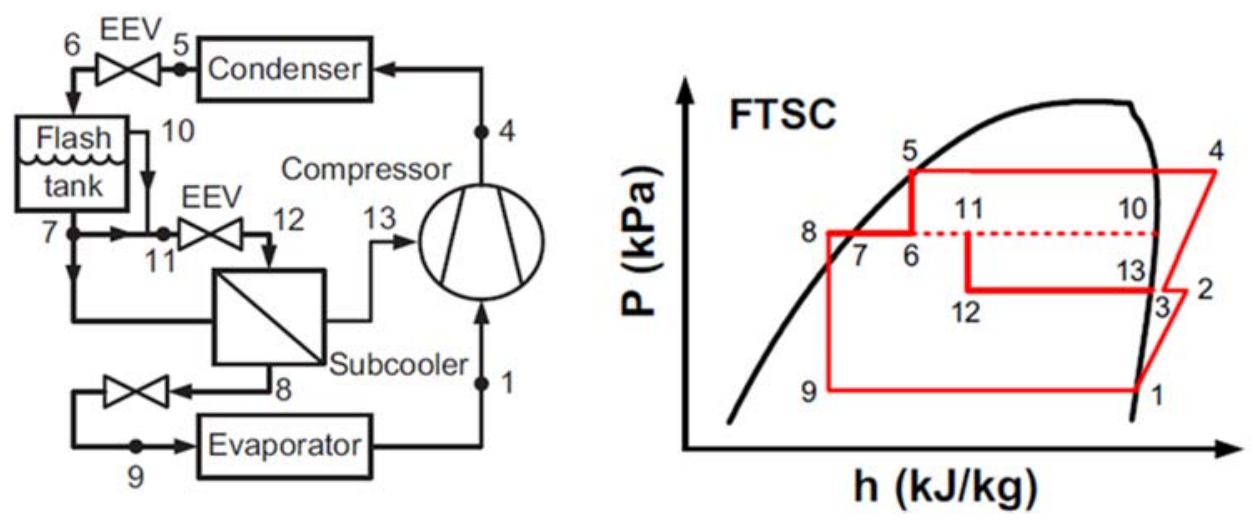

Fig.2. Flash tank and sub-cooler vapour injection air source heat pump [9].

Heo, Jeong [9] presented an experimental investigation to study the effect of a combination of the flash tank with subcooler (FTSC) cycle. Double expansion sub-cooler (DESC) with R410A was used and compared to a sub-cooler SC and flash tank FT cycle, as shown in Fig.2. The heating sizes of DESC, FTSC and FT cycles showed an improvement of $3.8 \%, 6.0 \%$ and $14.4 \%$ respectively, as compared to the SC cycle. 
Table 2. Summary of research on different components.

\begin{tabular}{|c|c|c|}
\hline References & Modification & Remarks \\
\hline $\begin{array}{l}\text { Marti, Erdal } \\
{[62]}\end{array}$ & $\begin{array}{l}\text { Gas-Liquid } \\
\text { cyclone (GLCC) separator }\end{array}$ & $\begin{array}{l}\text { - The separation efficiency drops exponentially when the } \\
\text { bubbles have smaller diameter than that of } 100 \% \\
\text { separation efficiency. }\end{array}$ \\
\hline $\begin{array}{l}\text { Kouba and } \\
\text { Shoham [63] }\end{array}$ & $\begin{array}{l}\text { Effects of gas-liquid } \\
\text { cylindrical cyclone (GLCC) } \\
\text { separator parameters. }\end{array}$ & $\begin{array}{l}\text { - The performance of GLCC depends on the tangential } \\
\text { velocity of the swirling fluid. }\end{array}$ \\
\hline $\begin{array}{l}\text { Rosado, } \\
\text { Chávez [64] }\end{array}$ & Using intercooler technique. & $\begin{array}{l}\text { - The COP enhanced by } 8.28 \% \text { that lead to the reduction in } \\
\text { ice freezing time by } 22.25 \% \text { or } 3 h \text { and } 39 \mathrm{~min} \text {. }\end{array}$ \\
\hline Kilıç [65] & $\begin{array}{l}\text { Intercooler using refrigerants } \\
\mathrm{R} 507, \mathrm{R} 404 \mathrm{a} \text {, and } \mathrm{R} 407 \mathrm{c} \text {. }\end{array}$ & $\begin{array}{l}\text { - The energy efficiency and COP of the R407c system is } \\
\text { better than for other refrigerants. } \\
\text { - The R507 refrigerant system has worst results due to the } \\
\text { total irreversibility rate. } \\
\text { - The refrigerants R407c, R507 and R404a may be used as } \\
\text { substitutes to replace CFCs refrigerants. }\end{array}$ \\
\hline $\begin{array}{l}\text { Zheng, Zhao } \\
{[66]}\end{array}$ & $\begin{array}{l}\text { Using vertical T-junction } \\
\text { separation into two phase flow } \\
\text { of R134a. }\end{array}$ & $\begin{array}{l}\text { - The separation efficiency deteriorated dramatically as the } \\
\text { vapor phase Froude number in the upward tube increased. }\end{array}$ \\
\hline $\begin{array}{l}\text { Kim, Jeon } \\
{[67]}\end{array}$ & $\begin{array}{l}\text { Numerical work to compare } \\
\text { the performance of liquid, } \\
\text { vapour, and two-phase } \\
\text { injection heat pumps with a } \\
\text { scroll compressor based on } \\
\text { the numerical model using } \\
\text { R410A. }\end{array}$ & $\begin{array}{l}\text { - The improvement in COP is more with decreasing outdoor } \\
\text { temperature. }\end{array}$ \\
\hline $\begin{array}{l}\text { Ruochen, } \\
\text { Shuxue [68] }\end{array}$ & $\begin{array}{l}\text { Experimental study to } \\
\text { investigate the injection } \\
\text { subcooling method to improve } \\
\text { the heating performance of } \\
\text { heat pump at cold regions } \\
\text { using R32 and compare it with } \\
\text { single stage, vapor injection } \\
\text { and liquid injection systems }\end{array}$ & $\begin{array}{l}\text { - The discharge temperature is decreased and the heating } \\
\text { performance is affected by the ratio of subcooling flow } \\
\text { rate. } \\
\text { - The COP of the new method system can be enhanced. }\end{array}$ \\
\hline $\begin{array}{l}\text { Min, Jang } \\
{[69]}\end{array}$ & $\begin{array}{l}\text { Theoretical work to study the } \\
\text { effect of vapor injection in a } \\
\text { multi-split VRF system using } \\
\text { injection cycle and injection } \\
\text { cycle in hot season. Results } \\
\text { are validated experimentally. }\end{array}$ & $\begin{array}{l}\text { - Increase in the cooling sizes with values of } 3.22 \% \text {. } \\
\text { - Energy efficient ratio (EER) with values of } 1.98 \% \text { and } \\
1.72 \% \text {, respectively. } \\
\text { - There is a reduction in the input power of the injection } \\
\text { cycle up to } 4.45 \% \text { when the bypass cycle and injection } \\
\text { cycle are compared with conventional cycle. }\end{array}$ \\
\hline
\end{tabular}

An experimental study was made to investigate the flash tank vapor injection FTVI effects on the performance of heating for a 2 stage heat pump with an inverter-driven twin rotary compressor with frequency range between 50 to $100 \mathrm{~Hz}$ at ambient temperatures of $-15,-5$, and $5^{\circ} \mathrm{C}$ [11]. The heating capacity and COP of the FTVI cycle increased by $10 \%$ and $25 \%$, respectively at $-15^{\circ} \mathrm{C}$ ambient temperature. An increase in the total mass flow rate of the FTVI is $30-38 \%$ higher than that of the conventional cycle. Figure 3 summarize the results.

All the previous studies focused on the improvement and reducing energy. Table 2 presents a summary of research on different components that can be used to improve the system performance. 

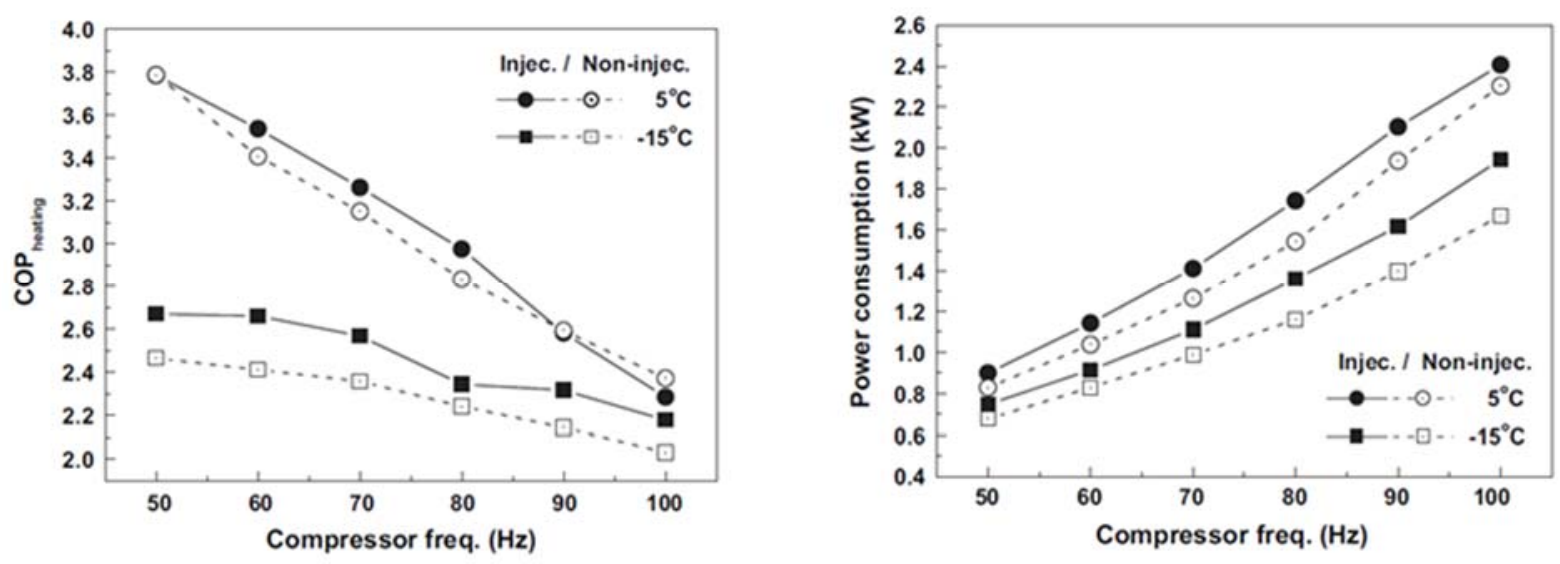

Fig.3. COP and power consumption [11].

\section{Future vision for vapour compresion refrigeration system}

The future vision for the vapor compression refrigeration systems should meet the high-performance and sustainability requirements. The future refrigeration system can be used without any negative effects on the system's reliability. From the system performance point of view, the system's reliability and efficiency are important parameters that need to be considered in the future design to meet the application and environmental needs . Therefore, many studies have provided different techniques to enhance the system performance such as Wang, Hwang [8], Wang, Shi [5], Wang, Shi [70], Heo, Jeong [9], Mathison, Braun [12] and Baek, Heo [71].

The vapour injection is one of the effective techniques which is used to obtain high performance of refrigeration systems. However, natural refrigerants need to be considered and used for the future refrigeration systems. Many studies are started to develop a suitable refrigeration system by redesign of the main component such as a compressor and/or addition of a new part to be suitable to work with the natural refrigerant (Wang, Wang [72], Wang and Müller [73] and Li, Piechna [74], Raid et al. [75]). Suggestions for the future research and investigations can be summarised as follows:

- System components such as vapour injection technique, subcooled technique, and vertical gravitational separator need to be investigated for the vapour compression systems to obtain high performance.

- Experimental investigation of natural refrigerants such as water need to be considered for the future refrigeration systems.

- Computational fluid dynamic (CFD) can be used to design the components of the vapor compression system and it can be used to predict the flow characteristics in refrigeration systems.

- CFD can be used to optimize the new design and enhance the vertical flash tank separator and other system's components such as the condenser and evaporator.

- More experimental studies on reducing losses in vapour compression refrigeration systems should be made.

\section{Conclusion}

An extensive review of the experimental and theoretical studies has been made to give a summary of the improvement of system performance for the vapour compression refrigeration systems. System modification using different techniques such as vapour injection has been presented through deep assessment of the literature. The results revealed that the vapour injection technique provides low energy consumption, high performance and reduces the thermal stress on the compressor because of reducing the discharge temperature. The review can be summarized as follows: 
- Injection subcooling method can improve the COP.

- Injection subcooling methods can decrease the discharge temperature.

- Vapour injection can be used with scroll compressor to improve the COP.

- Intercooling technique can enhance the COP by $8.28 \%$.

- R1234ze and R1234yf are alternative refrigerants that can be used to improve the COP.

- $\mathrm{R}-407 \mathrm{C}$ has lower performance compared with R22.

- R507 is an alternative refrigerant that can be used to improve the COP.

- CFD approach can provide high quality design and refrigerant flow prediction.

- Vertical gravitational flash tanks are very effective components that can improve the capacity and performance efficiently.

- Improvement of vertical flash tank separator leads to an improvement of the COP.

- Future vision of the refrigeration system discussed the future system design and requirements to meet the environmental and performance needs.

- More attention should be paid to CFD numerical modelling.

\section{ACKNOWLEDGEMENT}

Special thanks and gratitude go to the University of Southern Queensland and University of Zakho to promote the research..

\section{REFERENCES}

[1] Arpandi I.A. (1995): Hydrodynamics of two-phase flow in gas-liquid cylindrical cyclone separators.- SPE Journal: SPE 70th Annual Meeting, p.427.

[2] Jang Y., Lee E., Chin S. and Haet S. (2010): Effect of flash and vapor injection on the air-to-air heat pump system.International Refrigeration and Air Conditioning Conference, Purdue University School of Mechanical Engineering, pp.1-8

[3] Sirwan R., Ali Y., Zaharim A. and Sopian K. (2011): Effect of adding flash tank on the evaporator's thermal load of the combined ejector-absorption cooling system.- in Proceedings of the 10th WSEAS international conference on System Science and Simulation in Engineering., World Scientific and Engineering Academy and Society (WSEAS): Penang, Malaysia. p.124-127.

[4] Ma G. and Zhao H. (2010): Performance prediction for heat pump system with flash tank coupled with scroll compressor.- International Journal of Ambient Energy, vol.31, No.3, p.153-160.

[5] Wang B., Shi W. and Li X. (2009): Numerical analysis on the effects of refrigerant injection on the scroll compressor.- Applied Thermal Engineering, vol.29, No.1, pp.37-46.

[6] Guoyuan M., Qinhu C. and Yi J. (2003): Experimental investigation of air-source heat pump for cold regions.International Journal of Refrigeration, vol.26, No.1, pp.12-18.

[7] Heo J., Kang H. and Kim Y. (2012): Optimum cycle control of a two-stage injection heat pump with a double expansion sub-cooler.- International Journal of Refrigeration, vol.35, No.1, pp.58-67.

[8] Wang X., Hwang Y. and Radermacher R.(2009): Two-stage heat pump system with vapor-injected scroll compressor using $R 410 A$ as a refrigerant.- International Journal of Refrigeration, vol.32, No.6, pp.1442-1451.

[9] Heo J., Jeong M., Baek C. and Kim Y.(2011): Comparison of the heating performance of air-source heat pumps using various types of refrigerant injection.- International Journal of Refrigeration, vol.34, No.2, pp.444-453.

[10] Elbel S. and Hrnjak P. (2004): Flash gas bypass for improving the performance of transcritical R744 systems that use microchannel evaporators.- International Journal of Refrigeration, vol.27, No.7, pp.724-735.

[11] Heo J., Jeong M. and Kim Y. (2010): Effects of flash tank vapor injection on the heating performance of an inverterdriven heat pump for cold regions.- International Journal of Refrigeration, vol.33, No.4, pp.848-855. 
[12] Mathison M., Braun J. and Groll E. (2011): Performance limit for economized cycles with continuous refrigerant injection.- International Journal of Refrigeration, vol.34, No.1, pp.234-242.

[13] Mahmood R.A., Buttsworth D. and Malpress R. (2019): Computational and experimental investigation of using an extractor in the vertical gravitational flash tank separator.- International Journal of Automotive and Mechanical Engineering, vol.16, No.2, pp.6706-6722.

[14] Mahmood R.A., Buttsworth D., Malpress R. and Sharifian B. (2019): CFD numerical and experimental investigation of two-phase flow development after expansion device in a horizontal pipe.- Journal of Thermal Engineering, vol.7, No.1, pp.307-323.

[15] Ma G.-Y. and Zhao H.-X. (2008): Experimental study of a heat pump system with flash-tank coupled with scroll compressor.- Energy and Buildings, vol.40, No.5, pp.697-701.

[16] Xu X., Hwang Y. and Radermacher R. (2011): Transient and steady-state experimental investigation of flash tank vapor injection heat pump cycle control strategy.- International Journal of Refrigeration, vol.34, No.8, pp.1922-1933.

[17] Xu Y., Fang Su X., Zhou Z. and Chen W. (2012): Evaluation of frictional pressure drop correlations for two-phase flow in pipes.- Nuclear Engineering and Design, vol.253, pp.86-97.

[18] Sirwan R., Alghoul M., Sopian K., Ali Y. and Abdulateef J. (2013): Evaluation of adding flash tank to solar combined ejector-absorption refrigeration system.- Solar Energy, vol.91, pp.283-296.

[19] Qiao H., Aute V. and Radermacher R. (2015): Transient modeling of a flash tank vapor injection heat pump system - part I: Model development.- International Journal of Refrigeration, vol.49, pp.169-182.

[20]. Mahmood R.A., Buttsworth D. and Malpress R. (2019): Computational and experimental investigation of the vertical flash tank separator part 1: effect of parameters on separation efficiency.- International Journal of AirConditioning and Refrigeration, vol.27, No.1., https://doi.org/10.1142/S2010132519500056.

[21] Tuo H. and Hrnjak P. (2014): Vapor-liquid separation in a vertical impact T-junction for vapor compression systems with flash gas bypass.- International Journal of Refrigeration, vol.40, pp.189-200.

[22] Dhumane R., Qiao Y., Ling J., Muehlbauer J., Aute V., Hwang Y. and Radermacher R. (2019): Improving system performance of a personal conditioning system integrated with thermal storage.- Applied Thermal Engineering, vol.147, pp.40-51.

[23] Pathak A., Binder M., Ongel A. and Ng H. (2019): Investigation of a multi stage vapour-injection cycle to improve air-conditioning system performance of electric buses.- Fourteenth International Conference on Ecological Vehicles and Renewable Energies (EVER), 8-10 May 2019, IEEE, p.124-127.

[24] Soliman A.M., Rahman A. and Ookawara S. (2019): Enhancement of vapor compression cycle performance using nanofluids.- Journal of Thermal Analysis and Calorimetry, vol.135, No.2, pp.1507-1520.

[25] Qiao H., Xu X., Aute V. and Radermacher R. (2015): Transient modeling of a flash tank vapor injection heat pump system - part II: Simulation results and experimental validation.- International Journal of Refrigeration, vol.49, pp.183-194.

[26] Mahmood R.A. (2018): Experimental and computational investigation of gravity separation in a vertical flash tank separator.- PhD thesis, Faculty of Health, Engineering and Sciences, School of Mechanical and Electrical Engineering, University of Southern Queensland, p.246.

[27] Ansari N., Arora A. and Manjunath K. (2020): The effect of eco-friendly refrigerants on performance of vapor compression refrigeration system with dedicated mechanical subcooling.- Advances in Energy and Built Environment, Springer, pp.43-54.

[28] Ajayi O., Ukasoanya D., Ogbonnaya M., Salawu E., Okokpujie I., Akinlabi S., Akinlabi E. and Owoeye F. (2019): Investigation of the effect of R134a/Al2O3 - nanofluid on the performance of a domestic vapour compression refrigeration system.- Procedia Manufacturing, vol.35, pp.112-117.

[29] Siva Reddy V., Panwar N. and Kaushik S. (2012): Exergetic analysis of a vapour compression refrigeration system with R134a, R143a, R152a, R404A, R407C, R410A, R502 and R507A.- Clean Technologies and Environmental Policy, vol.14, No.1, pp.47-53.

[30] Mohanraj M., Muraleedharan C. and Jayaraj S. (2011): A review on recent developments in new refrigerant mixtures for vapour compression-based refrigeration, air-conditioning and heat pump units.- International Journal of Energy Research, vol.35, No.8, pp.647-669. 
[31] Arora A. and Kaushik S. (2008): Theoretical analysis of a vapour compression refrigeration system with R502, R404A and R507A.- International Journal of Refrigeration, vol.31, No.6, pp.998-1005.

[32] Cabello R., Torrella E. and Navarro-Esbrí J. (2004): Experimental evaluation of a vapour compression plant performance using R134a, R407C and R22 as working fluids.- Applied Thermal Engineering, vol.24, No.13, pp.1905-1917.

[33] Minh N., Hewitt N. and Eames P. (2006): Improved vapour compression refrigeration cycles: literature review and their application to heat pumps.- International Refrigeration and Air Conditioning Conference at Purdue, July 17-20, p.9.

[34] Mohanraj M., Muraleedharan C. and Jayaraj S. (2010): A review on recent developments in new refrigerant mixtures for vapour compression-based refrigeration, air-conditioning and heat pump units.- International Journal of Energy Research, vol.35, No.8, pp.647-669.

[35] Mahmood R.A. (2020): Case study of liquid suction heat exchanger in a mechanical refrigeration system using alternative refrigerants.- International Journal of Engineering and Technology. vol.9, No.3, pp.644-649.

[36] Mahmood R., Buttsworth D. and Malpress R. (2019): Computational and experimental investigation of using an extractor in the vertical gravitational flash tank separator.- International Journal of Automotive and Mechanical Engineering, vol.16, No.2, pp.6706-6722.

[37] Jie X., Xianmin G. and Liping X. (2017): Experimental study on performance of flash-tank vapor injection airsource heat pump system with refrigerant R32.- Energy Procedia, vol.142, pp.950-956.

[38] Winandy E. and Lebrun J. (2002): Scroll compressors using gas and liquid injection: experimental analysis and modelling.- International Journal of Refrigeration, vol.25, No.8, pp.1143-1156.

[39] Bolaji B.O. (2011): Performance investigation of ozone-friendly R404A and R507 refrigerants as alternatives to $R 22$ in a window air-conditioner.- Energy and Buildings, vol.43, No.11, pp.3139-3143.

[40] Sun Y., Wang T., Yang L., Hu L. and Zeng X. (2019): Research of an integrated cooling system consisted of compression refrigeration and pump-driven heat pipe for data centers.- Energy and Buildings, vol.187, pp.16-23.

[41] Tao Y., Hwang Y., Radermacher R. and Wang C. (2019): Experimental study on electrochemical compression of ammonia and carbon dioxide for vapor compression refrigeration system.- International Journal of Refrigeration, vol.104, pp.180-188.

[42] Agrawal N., Patil S. and Nanda P. (2017): Experimental studies of a domestic refrigerator using R290/R600a zeotropic blends.- Energy Procedia, vol.109, pp.425-430.

[43] Shaik S. and Babu T. (2017): Theoretical performance investigation of vapour compression refrigeration system using HFC and HC refrigerant mixtures as alternatives to replace R22.- Energy Procedia, vol.109, pp.235-242.

[44] Choudhari C. and Sapali S. (2017): Performance investigation of natural refrigerant R290 as a substitute to R22 in refrigeration systems.- Energy Procedia, vol.109, pp.346-352.

[45] Samuel K., Govindarajulu K. and Edison G. (2014): An experimental investigation and performance evaluation of $1.5 \mathrm{tr}$ window air-conditioner by using R22 R407C and R410A by varying the capillary pitch.- World Applied Sciences Journal, vol.29, No.11, pp.1468-1472.

[46] Devotta S., Padalkar A. and Sane N. (2005): Performance assessment of HC-290 as a drop-in substitute to HCFC22 in a window air conditioner.- International Journal of Refrigeration, vol.28, No.4, pp.594-604.

[47] Santini F., Bianchi G., Di Battista D., Villante C. and Orlandi M. (2019): Experimental investigations on a transcritical CO2 refrigeration plant and theoretical comparison with an ejector-based one.- Energy Procedia, vol.161, pp.309-316.

[48] Poachaiyapoom A., Leardkun R., Mounkong J. and Wongwises S. (2019): Miniature vapor compression refrigeration system for electronics cooling.- Case Studies in Thermal Engineering, vol.13, manuscript number 100365 .

[49] Branch K. and Khalkhal I. (2011): Performance comparison of R407c and R22 in offdesign point using Wilson-plot method.- Middle-East J. Sci. Res, vol.9, No.2, pp.177-183.

[50] Devotta S., Padalkar A. and Sane N. (2002): Experimental performance assessment of a retrofitted window air conditioner with R-407C.- International Refrigeration and Air Conditioning Conference, Paper Number 533. 
[51] Choi J. and Kim Y. (2004): Influence of the expansion device on the performance of a heat pump using R407C under a range of charging conditions.- International Journal of Refrigeration, vol.27, No.4, pp.378-384.

[52] Deymi-Dashtebayaz M. and Valipour-Namanlo S. (2019): Thermoeconomic and environmental feasibility of waste heat recovery of a data center using air source heat pump.- Journal of Cleaner Production, vol.219, pp.117-126.

[53] Agarwal S., Arora A. and Arora B. (2020): Exergy analysis of dedicated mechanically subcooled vapour compression refrigeration cycle using HFC-R134a, HFO-R1234ze and R1234yf.- Advances in Energy and Built Environment, Springer, vol.36, p. 23-42.

[54] Jain S., Jain G. and Bullard C. (2004): Vapor injection in scroll compressors.- International Compressor Engineering Conference. School of Mechanical Engineering, Purdue University Purdue. p.1-8.

[55] Hwang Y., Xu X., Radermacher R. and Pham H. (2010): Control strategy of vapor injection cycle.- International Refrigeration and Air Conditioning Conference, Purdue University School of Mechanical Engineering, p.1-9.

[56] Mahmood R., Buttsworth D. and Malpress R. (2019): Experimental and numerical investigation of two-phase flow orientation direction change on a vertical flash tank separator.- ISER 460th International Conference on Heat Transfer and Fluid Flow (ICHTFF), Brisbane, Australia, vol.5, No.4, pp.25-29.

[57] Mahmood R.A. (2020): CFD Assessment and experimental investigation of the liquid separation efficiency enhancements in a vertical gravity separator.- International Journal of Air-Conditioning and Refrigeration, vol.28, No.3, pp2050021.

[58] Llopis R., Nebot-Andres L., Sanchez D., Catalan-Gil J. and Cabello R. (2018): Subcooling methods for CO2 refrigeration cycles. A Review.- International Journal of Refrigeration, vol.93, pp.85-107.

[59] Jangir P. and Jana A. (2019): CFD simulation of droplet splitting at microfluidic T-junctions in oil-water two-phase flow using conservative level set method.- Journal of the Brazilian Society of Mechanical Sciences and Engineering, vol.41, No.2, Article number 75.

[60] Kumar P. and Chandrasekar M. (2019): CFD analysis on heat and flow characteristics of double helically coiled tube heat exchanger handling MWCNT/water nanofluids.- Heliyon, vol.5, No.7, pp.02030.

[61] Sharifi K., Sabeti M., Rafiei M., Mohammadi A. and Shirezi L. (2018): Computational fluid dynamics (CFD) technique to study the effects of helical wire inserts on heat transfer and pressure drop in a double pipe heat exchanger.- Applied Thermal Engineering, vol.128, pp.898-910.

[62] Marti S., Erdal F., Shoham O., Shirazi S. and Kouba G. (1996): Analysis of gas carry-under in gas-liquid cylindrical cyclones.- Hydrocyclones. London: London and Bury Saint Edmunds, pp.399-421.

[63] Kouba G. and Shoham O. (1996): A review of gas-liquid cylindrical cyclone (GLCC) technology.- Production Separation Systems, International Conference, Aberdeen, England. Aberdeen, England, p. 25.

[64] Rosado D., Chavez S., De Carvalho J. and Huallpachoque R. (2019): Comparison between the steam compression refrigeration system with intercooler and with compressor scale system: A case study.- Energy Conversion and Management, vol.183, pp.406-417.

[65] Kılıç B. (2012): Exergy analysis of vapor compression refrigeration cycle with two-stage and intercooler.- Heat and Mass Transfer, vol.48, No.7, pp.1207-1217.

[66] Zheng N., Zhao L., Hwang Y., Zhang J. and Yang X. (2016): Experimental study on two-phase separation performance of impacting T-junction.- International Journal of Multiphase Flow, vol.83, pp.172-182.

[67] Kim D., Jeon Y., Jang Do. and Kim Y. (2018): Performance comparison among two-phase, liquid, and vapor injection heat pumps with a scroll compressor using R410A.- Applied Thermal Engineering, vol.137, pp.193-202.

[68] Ruochen D. (2018): Heating performance comparison of different heat pump refrigerants at low temperature.Heating Ventilating and Air Conditioning, vol.1, p. 24.

[69] Min B., Jang S., Lee T., Bae H., Moon C. and Choi G. (2019): Performance comparison between bypass cycle and injection cycle for sub-cooling methods in multi-split variable refrigerant flow (VRF) system in hot seasons.International Journal of Refrigeration, vol.107, pp.202-213.

[70] Wang B., Shi W., Han L. and Li X. (2009): Optimization of refrigeration system with gas-injected scroll compressor.- International Journal of Refrigeration, vol.32, No.7, pp.1544-1554. 
[71] Baek C., He J., Jung J., Lee E. and Kim Y. (2014): Effects of vapor injection techniques on the heating performance of a CO2 heat pump at low ambient temperatures.- International Journal of Refrigeration, vol.43, pp.26-35.

[72] Wang F., Wang F., Fan X. and Lian Z. (2012): Experimental study on an inverter heat pump with HFC125 operating near the refrigerant critical point.- Applied Thermal Engineering, vol.39, pp.1-7.

[73] Wang J. and Müller N. (2012): Preliminary design and investigation of integrated compressor with composite material wheel.- Applied Composite Materials, vol.19, No.3, pp.739-746.

[74] Li Q., Piechna J. and Müller N. (2011): Thermodynamic potential of using a counter rotating novel axial impeller to compress water vapor as refrigerant.- International Journal of Refrigeration, vol.34, No.5, pp.1286-1295.

[75] Mahmood R., Omar M. and Noor N. (2020): Mechanical vapour compression refrigeration system: review part 1: environment challenge.- International Journal of Applied Mechanics and Engineering, vol.25, No.4, pp.130-147.

Received: March 19, 2021

Revised: July 22, 2021 